\title{
Structural Changes in Lettuce Seed During Germination at High Temperature Altered by Genotype, Seed Maturation Temperature, and Seed Priming
}

\author{
Yu Sung \\ Horticulture Department, National Chuang-Hsing University, Taichung, Taiwan \\ Daniel J. Cantliffe ${ }^{1}$ \\ University of Florida, Institute of Food and Agricultural Sciences, Horticultural Sciences \\ Department, 1251 Fifield Hall, P.O. Box 110690, Gainesville, FL 32611-0690 \\ Russell T. Nagata \\ Everglades Research and Education Center, 3200 East Palm Beach Road, Belle Glade, FL 33430 \\ Warley M. Nascimento \\ Embrapa Vegetables, C. Postal 218, Brasilia, DF, Brazil, 70359-970
}

AdDitional INDEX wORDs. Lactuca sativa, thermodormancy, seed enhancement, endosperm weakening

\begin{abstract}
To investigate thermotolerance in seeds of lettuce (Lactuca sativa $\mathrm{L}$.), primed, nonprimed, or seeds matured at $20 / 10$ and $30 / 20{ }^{\circ} \mathrm{C}$ (day/night on a 12-h photoperiod) were imbibed at $36^{\circ} \mathrm{C}$ for various periods and then dissected. Structural changes in seed coverings in front of the radicle tip were observed during germination at high temperature. Thermotolerant genotypes, 'Everglades' and PI 251245, were compared with a thermosensitive cultivar, 'Dark Green Boston'. In all seeds that germinated, regardless of seed maturation temperature or priming, a crack appeared on one side of the cap tissue (constriction of the endosperm membrane near the basal end of the seed) at the micropylar region and the endosperm separated from the integument in front of the radicle tip. Additional changes took place during imbibition in these seeds; the protein bodies in the vacuoles enlarged and gradually depleted, large empty vacuoles formed, the cytoplasm condensed, the endosperm shrank, the endosperm cell wall dissolved and ruptured, and then the radicle elongated toward this ruptured area. The findings suggested that the endosperm layer presented mechanical resistance to germination in seeds that could not germinate at $36^{\circ} \mathrm{C}$. Weakening of this layer was a prerequisite to radicle protrusion at high temperature. Seeds of 'Dark Green Boston', 'Everglades', and PI 251245 matured at $30 / 20{ }^{\circ} \mathrm{C}$ had greater thermotolerance than those matured at $20 / 10{ }^{\circ} \mathrm{C}$. Results of the anatomical study indicated that the endosperm cell walls in front of the radicle of seeds matured at $30 / 20{ }^{\circ} \mathrm{C}$ were more readily disrupted and ruptured during imbibition than seeds matured at $20 / 10{ }^{\circ} \mathrm{C}$, suggesting a reason why these seeds could germinate quickly at supraoptimal temperatures. Similar endosperm structural alterations also were observed in primed seeds. Priming led to rapid and uniform germination, circumventing the inhibitory effects of high temperatures. From anatomical studies conducted to identify and characterize thermotolerance in lettuce seed germination, we observed that genotype, seed maturation temperature, or seed priming had the ability to reduce physical resistance of the endosperm by weakening the cell wall and by depleting stored reserves leading to cell collapse.
\end{abstract}

Lettuce is an important salad crop that is grown year-round in the United States from either direct seeding or transplants. In both cases, lettuce seeds are often exposed to higher than the optimal temperatures, which results in poor and nonuniform germination, affecting stand establishment. The optimum temperature for germination of many lettuce cultivars is between 15 and $22{ }^{\circ} \mathrm{C}$ and germination may be inhibited above $27{ }^{\circ} \mathrm{C}$ (Cantliffe et al., 2000).

Lettuce seeds have been one of the most used model systems for studying germination. In an extensive study, we have established that the ability of lettuce seeds to germinate at high temperature depended equally on heritable and environmental factors (Kozarewa et al., 2006; Nascimento et al., 2000; Sung et al., 1998a). The ability of lettuce seeds to germinate at high temperatures is genotype-dependent, and thus, the genetic

Received for publication 17 Aug. 2007. Accepted for publication 18 Jan. 2008. ${ }^{1}$ Corresponding author. E-mail: djcant@ufl.edu. variation for high temperature tolerance exists among accessions of lettuce and related wild species (Bradford et al., 2006). Lettuce genotypes differ strongly in their upper temperature limit for germination and can be divided into thermosensitive and thermotolerant (Kozarewa et al., 2006; Nascimento et al., 2000; Sung et al., 1998b). These authors also reported that the thermotolerance character of lettuce seeds could be completely suppressed or the thermotolerance could be enhanced in certain lettuce genotypes depending on temperature during seed maturation. The thermotolerance character in lettuce is controlled by at least two genes and can be introduced by breeding because this trait is heritable (R.T. Nagata, unpublished data). The basis of the genotype-dependent thermotolerance is not clear and is probably related to more than one factor.

The "seed" of lettuce is actually a fruit (achene), but it will be referred as seed hereafter. In an early study on lettuce seed germination, Borthwick and Robbins (1928) linked the three tissues surrounding the embryo, namely the pericarp (ovary 
wall), integument, and endosperm, to germination inhibition at high temperature. The pericarp is a ribbed structure consisting of thick-walled, lignified cells. The integument is composed of the remnants of the outer epidermis and some parenchymous cells. The endosperm is two cells thick, except at the radicle end where it is three or more cells thick (Jones, 1974) and is composed largely of galactomannans (Halmer et al., 1975). Lettuce seeds contain living endosperm tissues that completely enclose the embryo. At high temperature, these tissues, especially the endosperm, act as a physical barrier, interfering with lettuce seed germination (Ikuma and Thimann, 1963; Nabors and Lang, 1971a, 1971b; Speer, 1974).

The major biochemical events that occur in germination of lettuce include activation of enzymes, mobilization of stored reserves and cell wall materials, and a decrease in endosperm weight (Psaras et al., 1981). Cell wall degrading enzymes located in the micropylar region of the endosperm tissue synthesized during imbibition may be a necessary prerequisite for normal germination. There is abundant evidence for this hypothesis: 1) increased germination by cutting the endosperm tissue (Ikuma and Thimann, 1963), 2) buckling of the embryo within an unweakened endosperm (Pavlista and Haber, 1970), 3 ) disruptions of the endosperm tissue in the micropylar region before the onset of germination (Pavlista and Valdovinos, 1978), 4) increased activity of carboxymethylcellulase before endosperm degradation (Pavlista and Valdovinos, 1975), 5) inducing significant germination after injection of cellulase and pectinase under the endosperm envelope (Ikuma and Thimann, 1963), 6) the appearance of mannanase activity in the micropylar cap before radicle protrusion (Dutta et al., 1997; Nascimento et al., 2000, 2001), and 7) the ability of seed priming to completely circumvent thermodormancy and the buildup of endo- $\beta$-mannanase during the priming process (Bonina et al., 2007; Nascimento et al., 2001).

Cell wall proteins and hydrolases are likely to have a mechanistic role in endosperm weakening in many species (Nonogaki et al., 2007). The role of endo- $\beta$-mannanase, the major enzyme responsible for galactomannan endosperm cell wall weakening, has been extensively studied in many species (Bewley, 1997; Dahal et al., 1997; Gong et al., 2005; Leviatov et al., 1995; Marraccini et al., 2001; Mo and Bewley, 2003; Nonogaki et al., 1995, 2000; Sanchez and Miguel, 1997; Still and Bradford, 1997; Toorop et al., 1996; Willians et al., 2001). In lettuce, several isoforms of endo- $\beta$-mannanase using isoelectric focusing have been detected in germinating seeds (Nonogaki and Morohashi, 1999; Wang et al., 2004). Although several re- searchers have analyzed these enzymes, the identification and localization of the cell wall degrading enzyme(s) had been in question (Bewley and Halmer, 1980/1981; Dutta et al., 1994, 1997; Halmer et al., 1976; Ikuma and Thimann, 1963; Nascimento et al., 2000, 2001, 2004, 2005; Nonogaki et al., 2007; Ouellette and Bewley, 1986).

Structural changes in the endosperm before radicle protrusion have been reported in many species (Nonogaki et al., 2007), including lettuce (Georghiou et al., 1983; Psaras et al.,

Table 1. Effects of priming on high temperature germination of lettuce seeds.

\begin{tabular}{llcc}
\hline Cultivar & & \multicolumn{2}{c}{ Germination at $36^{\circ} \mathrm{C}$} \\
\cline { 3 - 4 } (thermosensitivity) & Treatment & Final $(\%)$ & $\mathrm{T}_{50}(\mathrm{~h})^{\mathrm{z}}$ \\
\hline Dark Green Boston & Nonprimed & 0 & Not available \\
$\quad$ (sensitive) & Primed & 86 & 16 \\
Everglades (tolerant) & Nonprimed & 95 & 26 \\
& Primed & 100 & 12 \\
PI251245 (tolerant) & Nonprimed & 93 & 17 \\
& Primed & 100 & 12 \\
\hline
\end{tabular}

${ }^{\mathrm{z}} \mathrm{T}_{50}=$ time for $50 \%$ of final germination to occur.
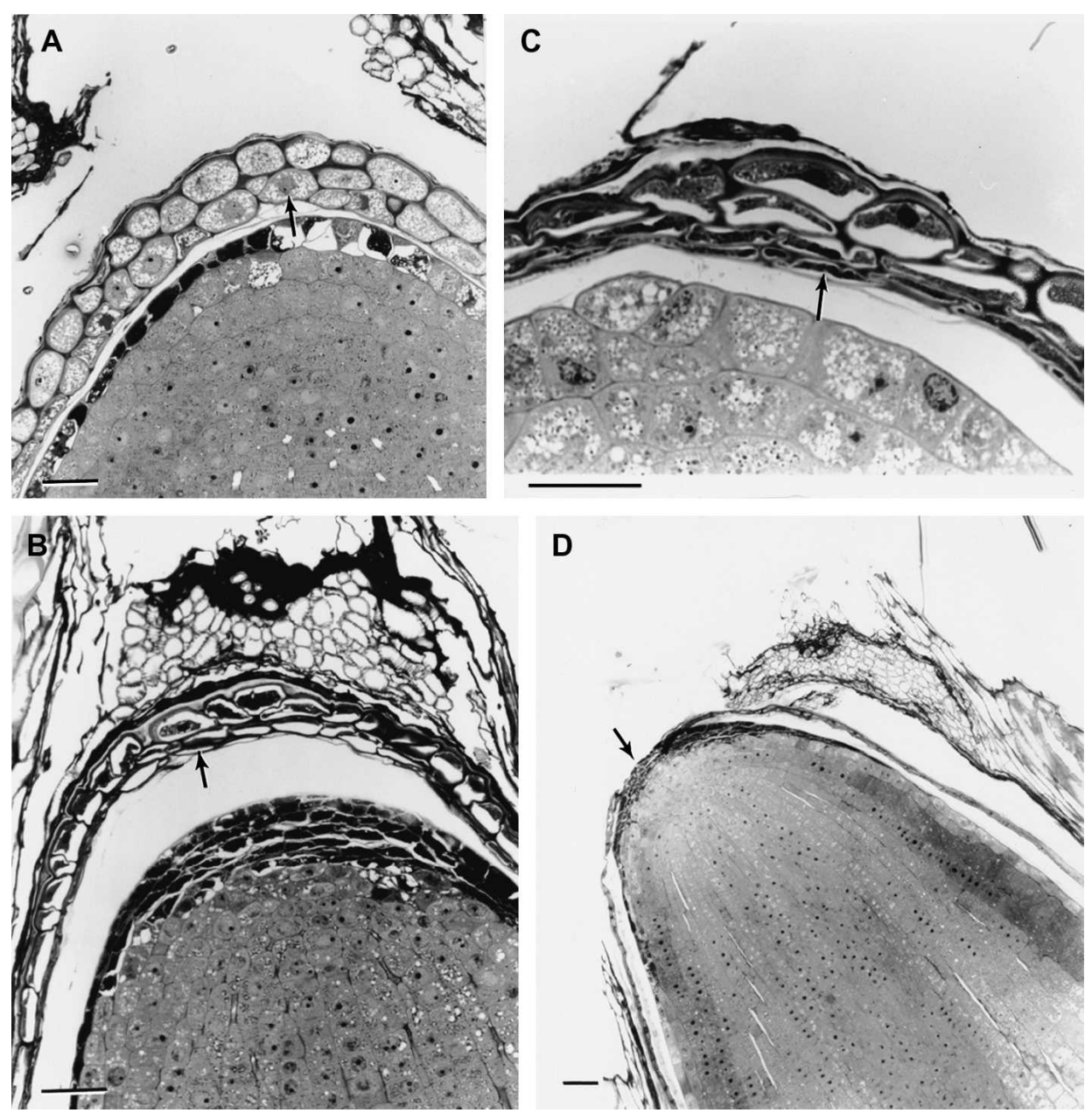

Fig. 1. Thin sections of 'Dark Green Boston' lettuce seeds imbibed at $36^{\circ} \mathrm{C}$. (A) Nonprimed seeds imbibed for $9 \mathrm{~h}$ showing numerous vacuoles in the endosperm. (B) Primed seed imbibed for $9 \mathrm{~h}$ with cytoplasm condensed. (C) Nonprimed seed imbibed for $13 \mathrm{~h}$ depicting condensed cytoplasm. (D) Primed seed imbibed for $13 \mathrm{~h}$ showing thin endosperm ruptured in front of the radicle $(\mathrm{bar}=30 \mu \mathrm{m})$. 
1981). Pavlista and Valdovinos (1978) used a scanning electron microscope to observe the disruption of the endosperm of 'Grand Rapids' lettuce seeds before germination. Cracks and pits along the walls and surface of the endosperm cells were evident, and the tip of the micropylar region of some achenes had large breaks. Endosperm disruption was also determined in imbibed achenes at $12 \mathrm{~h}$. Endosperm weakening was enhanced in light-treated seeds and the cytoplasm of the micropylar endosperm cells underwent drastic changes. Although the cell walls of the entire endosperm remained intact, the cells became highly vacuolated and reserve materials (protein and lipid) were mobilized (Psaras et al., 1981). The one exception was the study of Nijsse et al. (1998) in which there was no anatomical evidence for structural changes on the lettuce endosperm during seed imbibition in high temperature, far-red irradiation, or polyethylene glycol. These authors used a low-temperature scanning electron microscopy procedure and suggested that lettuce germination was not associated with general breakdown or digestion of the entire endosperm at the micropylar region.

The environmental conditions during seed development and maturation affect the ability of lettuce seeds to germinate at supraoptimal temperatures (Gray et al., 1988; Koller, 1962; Sung et al., 1998b). For example, high temperatures during lettuce seed maturation increase seed germination at high temperature from a thermosensitive genotype (Sung et al., 1998b). This ability of higher temperatures to improve germination may be related to different factors, which are not totally clear.

Priming circumvents thermoinhibition in lettuce seeds (Bradford and Somasco, 1994; Cantliffe et al., 1981; Guedes and Cantliffe, 1980; Nascimento and Cantliffe, 1998). Enzyme and metabolic activity were enhanced during lettuce seed priming and were related to increased seed germination rate (Khan et al., 1978; Nascimento et al., 2001). It is also possible that priming affects key metabolic processes related to the breakdown of protein, carbohydrates, and lipid reserve materials (Khan et al., 1980/1981). This degradation of stored reserves may increase the ability of the primed seeds to absorb water, to germinate rapidly, and to tolerate a stressful environment (Khan, 1992).

Puncture tests have been conducted to analyze the role of the physical barrier presented by seed coverings during germination of pepper (Capsicum annuum L.), tomato (Solanum lycopersicum L.), muskmelon (Cucumis melo L.), coffee (Coffea arabica L.), Brassicacea, and lettuce (Groot and Karssen, 1987; Müller et al., 2006; Silva et al.,
2005; Sung et al., 1998a; Tao and Khan, 1979; Watkins and Cantliffe, 1983; Welbaum et al., 1995). These results suggested that various parts of the seed coverings played a major role in controlling germination. Although weakening of endosperm is a prerequisite for many seeds, embryo growth is essential for germination of all seeds (Nonogaki et al., 2007). In lettuce seeds, the mechanism(s) that results in increased embryonic growth or weakening of the endosperm is still unknown. Lettuce genotypes with higher levels of thermotolerance exist and the ability of the seeds to germinate at high temperature can be enhanced by the environment during seed production (Gray et al., 1988; Sung et al., 1998b) using primed seeds (Cantliffe et al., 1981; Guedes and Cantliffe, 1980; Khan et al., 1978; Nascimento and Cantliffe, 1998; Nascimento et al., 2001; Sung et al., 1998a) or applying exogenous ethylene (Dutta and Bradford, 1994; Kozarewa et al., 2004; Nascimento et al., 2004) or other hormones (Gonai et al., 2004) during seed imbibition. The objective of this research was to identify the structural alterations in the micropylar area of lettuce seeds
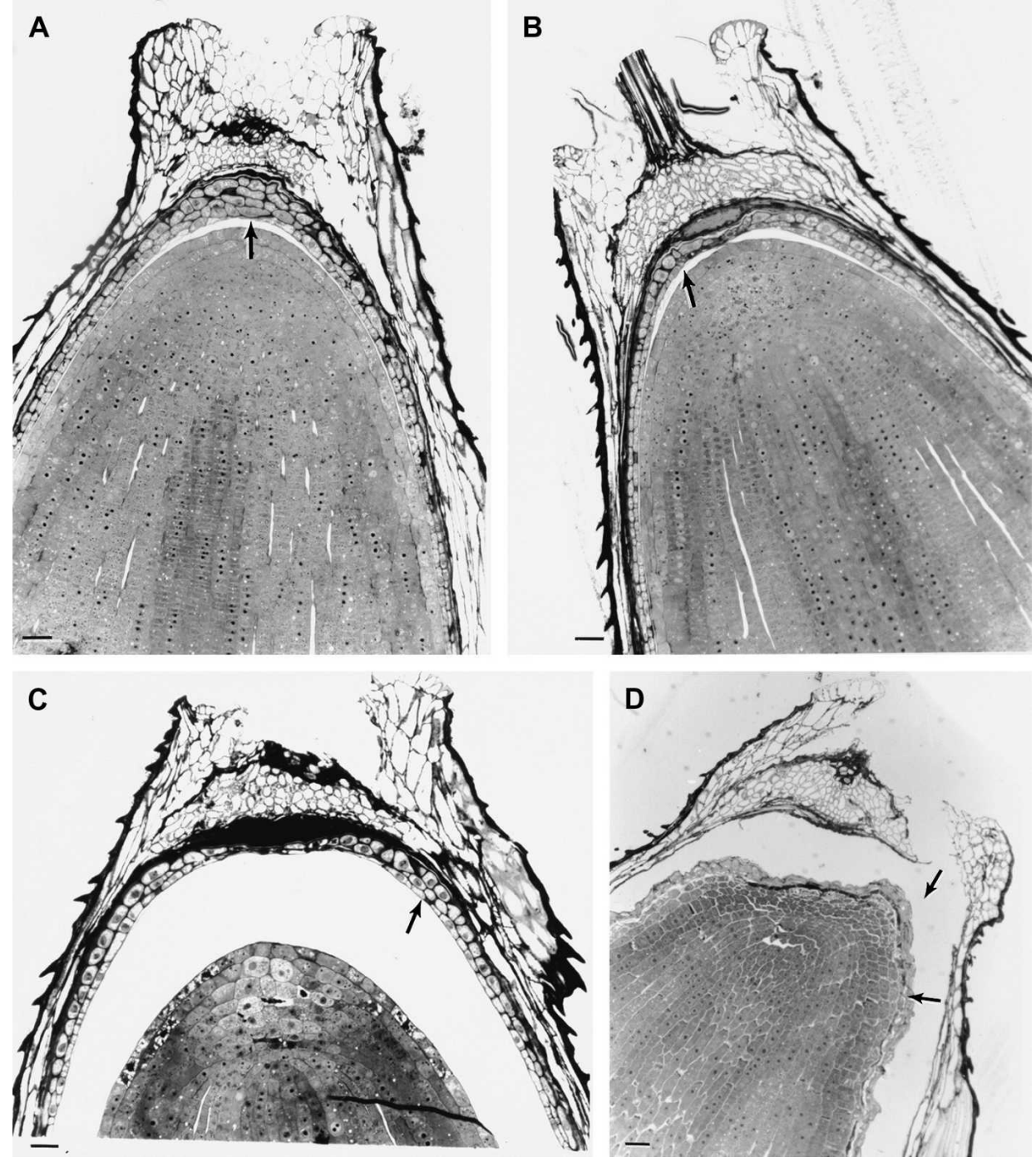

Fig. 2. Thin sections of 'Everglades' lettuce seeds imbibed at $36^{\circ} \mathrm{C}$. (A) Normal four-cell endosperm thickness in front of the radicle tip after 5-h imbibition. (B) Endosperm away from the radicle tip still has two-cell thickness after $5 \mathrm{~h}$ imbibition. (C) Endosperm cells in some seeds maintain cell integrity after $14 \mathrm{~h}$ imbibition, whereas others did not. (D) The endosperm layer surrounding the embryo develops a crack at one side of the cap structure. Note irregular shape of the apical tip of the radicle denoting growth (bar $=30 \mu \mathrm{m})$. 
during germination at high temperature as the seeds overcome thermoinhibition.

\section{Materials and Methods}

Plant material. One thermosensitive ['Dark Green Boston' (DGB)] and two thermotolerant ['Everglades' (EVE) and PI 251245 (PI)] genotypes were used as described by Sung et al., (1998b). Seeds of the three genotypes were also produced in the Salinas area of California. They were primed using the priming method as described by Sung et al. (1998a). Seeds were soaked in an aerated polyethylene glycol solution using an $\psi_{\mathrm{S}}$ of -1.2 (DGB) and -1.3 MPa (EVE and PI) and incubated at $15^{\circ} \mathrm{C}$ under constant light for 4 (DGB) and $2 \mathrm{~d}$ (EVE and PI). Seeds of 'Dark Green Boston', 'Everglades', and PI 251245 also were produced in growth chambers at $20 / 10$ or $30 / 20{ }^{\circ} \mathrm{C}$ (day/night temperatures on a 12-h photoperiod). The method of seed production was described by Sung et al. (1998b).

Germination tests. Primed and nonprimed seeds and seeds matured at $20 / 10$ and $30 / 20{ }^{\circ} \mathrm{C}$ were germinated at $36{ }^{\circ} \mathrm{C}$ in $12 / 12 \mathrm{~h} \mathrm{light} /$ dark $\left(\approx 10 \mu \mathrm{mol} \cdot \mathrm{m}^{-2} \cdot \mathrm{s}^{-1}\right)$ periods. Thirty seeds per replication per treatment were placed in a $5.5-\mathrm{cm}$-diameter petri dish with two layers of 4.5-cm-diameter Whatman \#3 filter paper (Whatman Intl., Ltd., Maidstone, England) moistened with 1 to $2 \mathrm{~mL}$ of distilled water. Distilled water was added as needed to keep the filter paper moist. Germination was defined as visible radicle protrusion through the pericarp and total percent germination was calculated. All treatments had three replications.

Sectioning. Eighty primed and nonprimed seeds from each genotype were placed on moist filter paper in a 5.5-cm-diameter petri dish and incubated for various periods in a 12/12 h light/dark at $36{ }^{\circ} \mathrm{C}$. After a prescribed time, the imbibed seeds were transversely cut in half and the micropylar region (Sung, 1996) was fixed in Trump solution $[10 \mathrm{~mL}$ of formaline: glacial acetic acid:alcohol, 10:5:85 $\mathrm{v} / \mathrm{v}+0.2 \%$ glutaraldehyde in $0.5 \mathrm{M}$ phosphate buffer at pH 7.2 (McDowell et al., 1976)] and stored for later use. Two sampling times per genotype were undertaken: immediately before radicle emergence as observed through a binocular microscope and when close to $30 \%$ of the seed lot had radicle protrusion. Eighty seeds of each genotype matured at 20/10 and $30 / 20{ }^{\circ} \mathrm{C}$ were treated in the same manner as described previously.

Fixed seeds were rinsed three times with $0.1 \mathrm{M}$ sodium cacodylate buffer at $\mathrm{pH} 7.2$ for $10 \mathrm{~min}$ at room temperature, dehydrated in a graded ethanol series (10 min each step) followed by $10 \mathrm{~min}$ in $100 \%$ acetone twice, then embedded in a LR White resin (London Resin Co., Surrey, UK) series for $4 \mathrm{~d}$. Polymerization of LR White resin was carried out at 52 to $57{ }^{\circ} \mathrm{C}$ for 2 $\mathrm{d}$ (Hall and Hawes, 1991). Sections $1 \mu \mathrm{m}$ thick were cut with a glass knife on a LKB 8800 Ultratome III (LKB-Produkter AB, Stockholm-Bromma, Sweden) and were routinely stained in $0.5 \%$ azure II $+0.5 \%$ methylene blue. Six primed seeds and eight seeds produced at each of the two temperature regimes were photographed using a light microscope (HFX Microflex; Nikon, Garden City, NY).

Endosperm cells in the micropylar area of 'Dark Green Boston' and 'Everglades' seeds matured at $20 / 10$ or $30 / 20{ }^{\circ} \mathrm{C}$ were counted under a light microscope. A minimum of three observations of each seed section were photographed using a light microscope (Nikon).

\section{Results}

\section{Structural alterations in primed and nonprimed seeds}

At two imbibition times, depending on the time of radicle protrusion for the various genotypes, structural alterations of the endosperm tissue of primed and nonprimed seeds were observed at the micropylar area, the region of radicle protrusion.
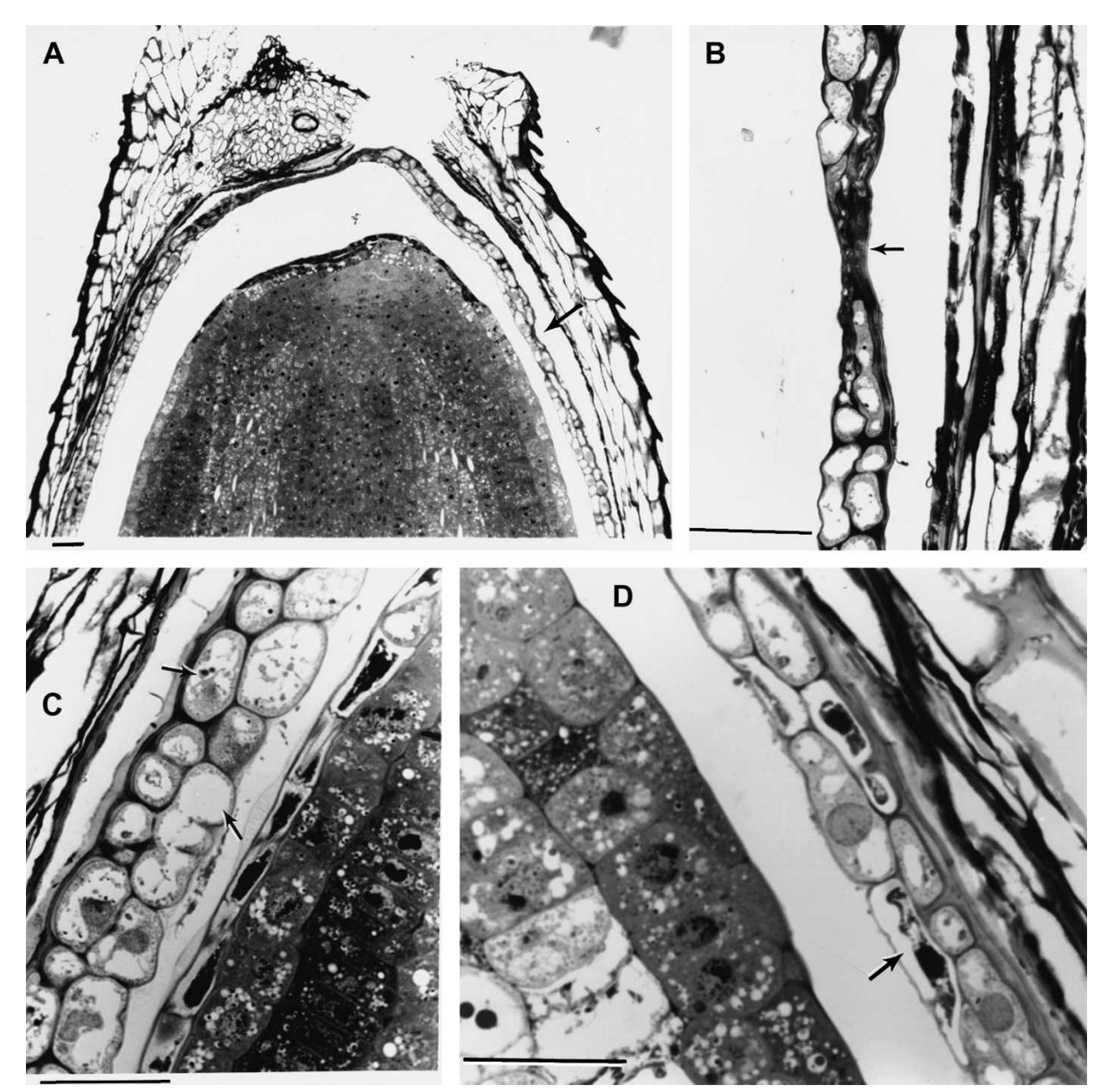

Fig. 3. Thin sections of 'Everglades' lettuce seeds after priming and reimbibing for $5 \mathrm{~h}$ at $36^{\circ} \mathrm{C}$. (A) A crack has appeared at one side of the cap structure as the endosperm has separated from the integument. Note the irregular shape of the radicle tip denoting growth. (B) A closeup of the endosperm showing the cytoplasm with varying degrees of density in this area. (C-D) Closeup of the endosperm depicting large vacuoles and protein bodies in the vacuole $(\mathrm{bar}=30 \mu \mathrm{m})$ 


\section{'Dark Green Boston' (thermosensitive)}

At $36{ }^{\circ} \mathrm{C}$, primed seeds had $86 \%$ germination $[16 \mathrm{~h}$ to achieve $50 \%$ of final seed germination $\left(\mathrm{T}_{50}\right)$ ]; nonprimed seeds did not germinate (Table 1). After primed and nonprimed seeds were imbibed for $9 \mathrm{~h}$, a crack appeared on one side of the cap tissue of the pericarp and integument of the primed seeds. Endosperm cells of nonprimed seeds were round and had small vacuoles spread throughout the cytoplasm (Fig. 1A). The radicle protruded through the seed coverings of primed seeds after $9 \mathrm{~h}$ of imbibition. The embryo of primed seeds was tightly enveloped by the endosperm layers and cells of the inner layer (close to the embryo) of the endosperm appeared to be thinner than the cells of the outer layer (close to the integument) (Fig. 1B).

After nonprimed seeds were imbibed for $13 \mathrm{~h}$, the cytoplasm in the micropylar area appeared condensed (Fig. 1C). In the inner layer of the endosperm tissue, cells appeared flattened, whereas at the outer layer, the cells were more round. Cell walls in the outer layer were thicker than those in the inner layer. Endospermal cytoplasm became less condensed after $13 \mathrm{~h}$ than $9 \mathrm{~h}$ imbibition. Primed seeds were imbibed for $13 \mathrm{~h}$; the endosperm layer had become thinner than the nonprimed seeds at $13 \mathrm{~h}$, cracked, and the radicle was able to push through this layer (Fig. 1D). A break in the endosperm tissue in front of the radicle was noted and the disappearance of cell walls of the endosperm tissue was noticeable in these seeds.

\section{'Everglades' (thermotolerant)}

Germination at $36{ }^{\circ} \mathrm{C}$ of primed 'Everglades' seeds was $100 \%\left(\mathrm{~T}_{50}=12 \mathrm{~h}\right)$ and for nonprimed $95 \%\left(\mathrm{~T}_{50}=26 \mathrm{~h}\right)($ Table 1). Some radicles of primed and nonprimed seeds protruded after 6 and $12 \mathrm{~h}$ of imbibition, respectively. After nonprimed (Fig. 2A-B) seeds were imbibed for $5 \mathrm{~h}$, seed structure appeared unaltered. Although compaction of endosperm cells on one side of the cap tissue in the micropylar region occurred in some seeds (Fig. 2D), this endosperm maintained integrity after $14 \mathrm{~h}$ of imbibition in other seeds. When primed seeds were imbibed for $5 \mathrm{~h}$, a crack appeared in one side or the other of the endosperm cap (Fig. 3A-B), whereas cells were vacuolated (Fig. $3 \mathrm{C}-\mathrm{D})$. The gap in primed seeds was larger after $5 \mathrm{~h}$ than that in nonprimed seeds after $14 \mathrm{~h}$. This crack or gap appeared to act as an opening for embryo tissues to expand and grow.

In primed seeds, there was a weak, narrow region in the loosened endosperm tissue. Around this region, the endosperm cells had dense cytoplasm, no vacuole, and were shrunken (Fig. 3B). A rupture of the endosperm layer was visible after 5 to $6 \mathrm{~h}$. In some endosperm cells, the inner cell wall had ruptured and the cytoplasm had flowed into the space between the endosperm and embryo. After primed seeds were imbibed for $6 \mathrm{~h}$, the endosperm tissue had the same structural alterations as those imbibed $5 \mathrm{~h}$ (data not shown).

After being imbibed for $14 \mathrm{~h}$, the growing radicle of nonprimed seeds was closely enveloped by the endosperm layer, which became narrow and wrinkled but remained intact (Fig. $2 \mathrm{C}$ ). An opening on one side of the pericarp and integument appeared and radicle tissues had grown preferentially toward this opening (Fig. 2D).

\section{PI 251245 (thermotolerant).}

Germination of primed seeds at $36{ }^{\circ} \mathrm{C}$ was $100 \%(12 \mathrm{~h}$ to $50 \%$ of final seed germination) and nonprimed seeds was $93 \%$ $\left(\mathrm{T}_{50}=17 \mathrm{~h}\right)($ Table 1$)$. In primed seeds imbibed for 3 and $4 \mathrm{~h}$, some endosperm cells were disrupted and had dense cytoplasm (data not shown). Rupture of some endosperm cell walls was also observed. The radicle of some primed seeds protruded after only $4 \mathrm{~h}$ of imbibition. A comparison was made of the median longitudinal sections of the micropylar area of nonprimed seeds after $17 \mathrm{~h}$ imbibition and of primed seeds after $3 \mathrm{~h}$ imbibition. After imbibition of nonprimed and primed seeds, the cytoplasm of the endosperm cells was condensed in the open (cracked)

Table 2. Effects of seed maturation temperature regime on high temperature germination of lettuce.

\begin{tabular}{lccc}
\hline $\begin{array}{l}\text { Cultivar } \\
\text { (thermosensitivity) }\end{array}$ & $\begin{array}{c}\text { Maturation temp } \\
\text { (day/night) }\end{array}$ & \multicolumn{2}{c}{ Germination at $36{ }^{\circ} \mathrm{C}$} \\
\cline { 3 - 4 } & $20 / 10^{\circ} \mathrm{C}$ & 2 & 24 \\
\hline Dark Green & $30 / 10{ }^{\circ} \mathrm{C}$ & 74 & 17 \\
Boston (sensitive) & $20 / 10{ }^{\circ} \mathrm{C}$ & 50 & 18 \\
Everglades (tolerant) & $30 / 10^{\circ} \mathrm{C}$ & 98 & 18 \\
& $20 / 10{ }^{\circ} \mathrm{C}$ & 33 & 26 \\
PI251245 (tolerant) & $30 / 10^{\circ} \mathrm{C}$ & 97 & 12
\end{tabular}

${ }^{\mathrm{z}} \mathrm{T}_{50}=$ time for $50 \%$ of final germination to occur.
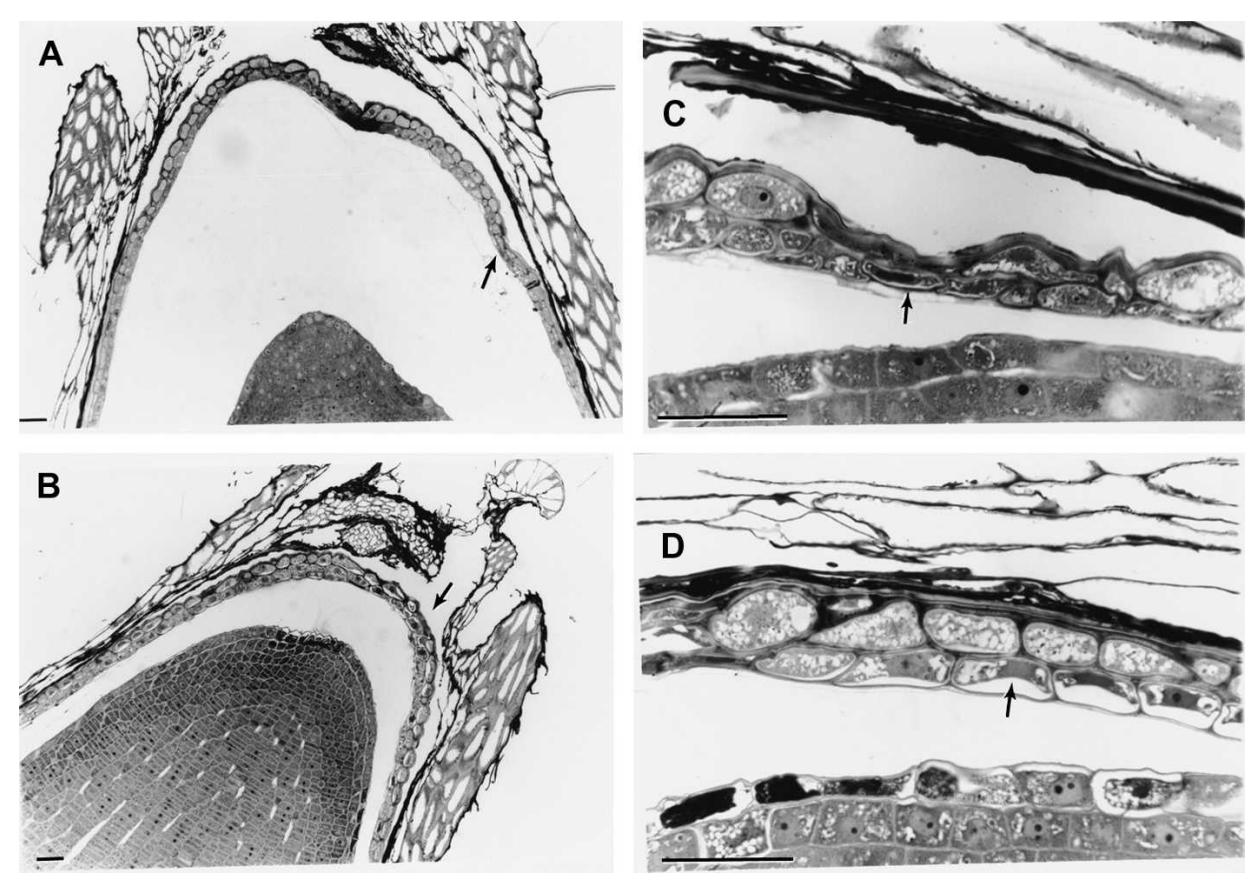

Fig. 4. Thin sections of 'Dark Green Boston' lettuce seeds matured at $20 / 10^{\circ} \mathrm{C}$ (day/night on a 12-h photoperiod) and subsequently imbibed at $36{ }^{\circ} \mathrm{C}$ for $15 \mathrm{~h}$. Only $2 \%$ of the seeds germinated. (A) A crack appeared at one side of the endosperm. (B) The endosperm separated from the integument. (C-D) Cytoplasm had varying degrees of density in the area near the crack (C) and frontal portion of the endosperm cap (D) (bar $=30 \mu \mathrm{m})$. 
area. The endosperm cells on the lateral side had numerous small vacuoles containing protein bodies, and walls of the outer cells were thicker than those of the inner cells (data not shown). In primed seeds, cell walls of the endosperm layer had already ruptured (data not shown).

After primed seeds were imbibed for $3 \mathrm{~h}$, disruption of endosperm cells in the gap area was visible. The cytoplasm of the disrupted cells was not dense, and some vacuoles and protein bodies were present, although cell walls had ruptured and the cellular content had disappeared. Nevertheless, intact endosperm tissue could be observed in some primed seeds after $3 \mathrm{~h}$ imbibition.

\section{Structural alterations in seeds matured at two temperature regimes}

'Dark Green Boston'. Final germination at $36{ }^{\circ} \mathrm{C}$ of seeds produced at $20 / 10{ }^{\circ} \mathrm{C}$ was only $2 \%\left(\mathrm{~T}_{50}=24 \mathrm{~h}\right)$ and for seeds produced at $30 / 20{ }^{\circ} \mathrm{C}$, $74 \%$ germination occurred $\left(\mathrm{T}_{50}=17 \mathrm{~h}\right)$ (Table 2). After $10 \mathrm{~h}$ of imbibition, seeds produced at $30 / 20{ }^{\circ} \mathrm{C}$ had over $30 \%$ germination. A two-cell thickness of endosperm layer separated from the integument, and some of the endosperm cells had shrunk after $15 \mathrm{~h}$ imbibition in seeds matured at 20/10 ${ }^{\circ} \mathrm{C}$ (Fig. 4A-B). Cytoplasm of the endosperm cells had varying density (Fig. 4C-D). There were numerous small vacuoles containing protein bodies in the endosperm cells. The size of individual vacuoles increased after 10 and $15 \mathrm{~h}$ of imbibition and the cytoplasm gradually became condensed in these seeds.

Normally, the central thickest area of the endosperm directly in front of the radicle tip contained five endosperm cell layers, which decreased to four, three, and two moving laterally away from the radicle tip. Many of the seeds that matured at $20 / 10{ }^{\circ} \mathrm{C}$ had a wider expanse of this five-celled area.

The endosperm layer of seeds matured at $30 / 20{ }^{\circ} \mathrm{C}$ ruptured in the micropylar area after $10 \mathrm{~h}$ of imbibition at $36^{\circ} \mathrm{C}$ (Fig. 5A-D). In endosperm cells, the cytoplasm appeared to have varying degrees of density. The endosperm layer ruptured at the thinnest point of the endosperm tissue (Fig. 5A). Some round cells on the lateral side of the endosperm layer had vacuoles containing protein bodies, and the inner cell wall appeared broken (Fig. 5B). Cells on the lower lateral side of endosperm layer had a thick, integrated cell wall structure (Fig. 5A).

'Everglades'. Germination at $36{ }^{\circ} \mathrm{C}$ of seeds matured at $20 / 10{ }^{\circ} \mathrm{C}$ was $50 \%$ and for seeds matured at $30 / 20{ }^{\circ} \mathrm{C}$ was $98 \%$,
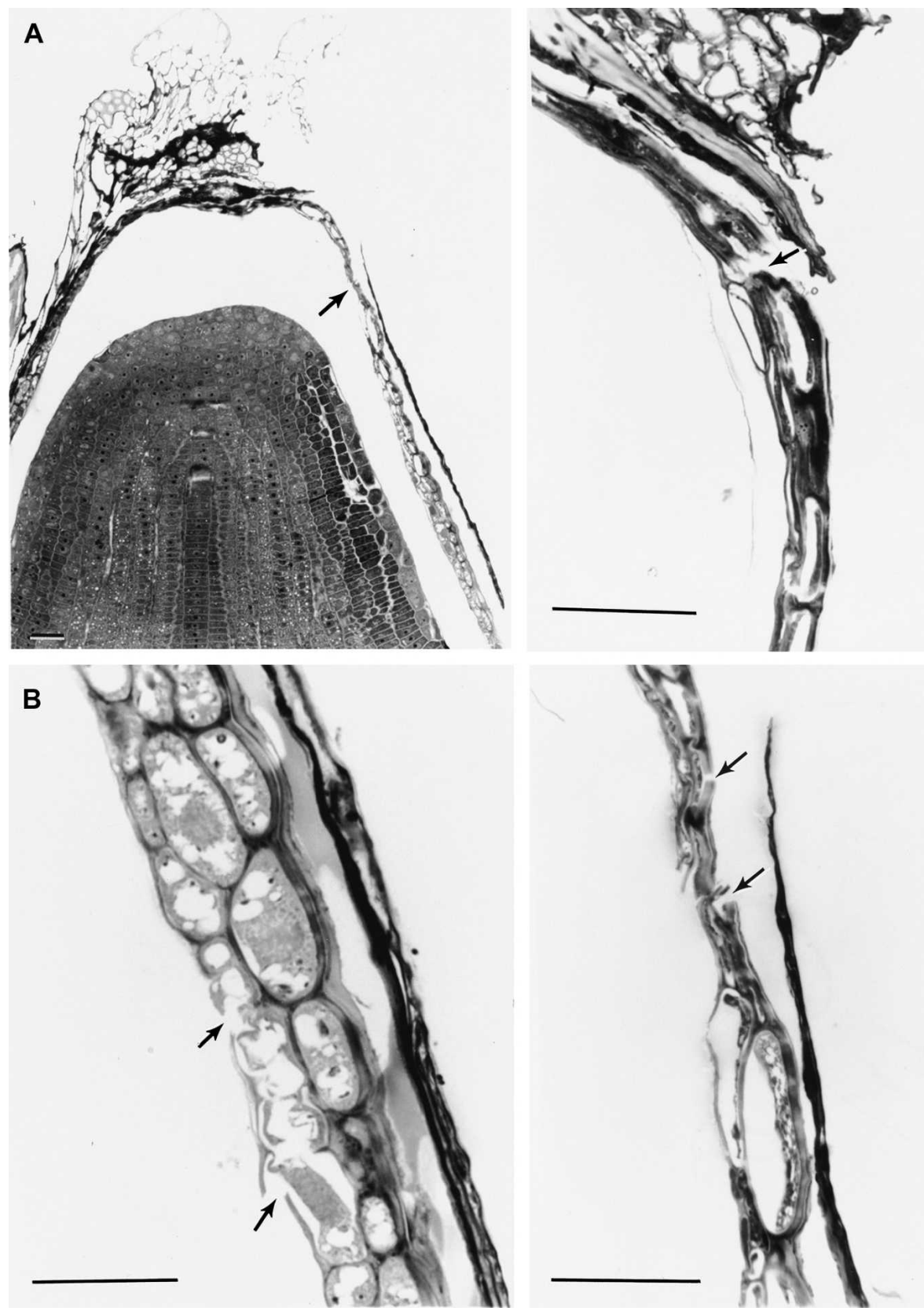

D

g. 5hin sections of 'Dark Green Boston' lettuce seeds matured at 30/20 ${ }^{\circ} \mathrm{C}$ (day/night on a 12 -h photoperiod) and subsequently imbibed at $36^{\circ} \mathrm{C}$ for $10 \mathrm{~h}$. A total of $74 \%$ of the seeds germinated. (A) Shrunken area of the endosperm and to the side of the radicle tip. (B) Endosperm wall rupture on the radicle side. (C) Endosperm cell wall disruption and (D) endosperm wall disruption and breakage (bar $=30 \mu \mathrm{m})$.

both taking $18 \mathrm{~h}$ to reach $50 \%$ of final germination (Table 2). After $10 \mathrm{~h}$ of imbibition, the radicle of some seeds matured at either temperature regime protruded through the endosperm. The endosperm layer in the micropylar region had more cells and greater cell thickness in seeds matured at $20 / 10{ }^{\circ} \mathrm{C}$ (Fig. $6 \mathrm{~A}-\mathrm{C}$ ). One side of the endosperm tissue had separated from the integument (Fig. 6D). In some cases, the endosperm layer of seeds matured at $20 / 10^{\circ} \mathrm{C}$ had ruptured and the endosperm cells were disrupted (Fig. 6C). In other cases, these seeds had flat endosperm cells with a thin layer at the micropylar area; the outer cell was thicker and inner cell walls of some showed evidence of dissolution (data not shown), whereas in others, part of the endosperm layer had shrunk (Fig. 6B). 

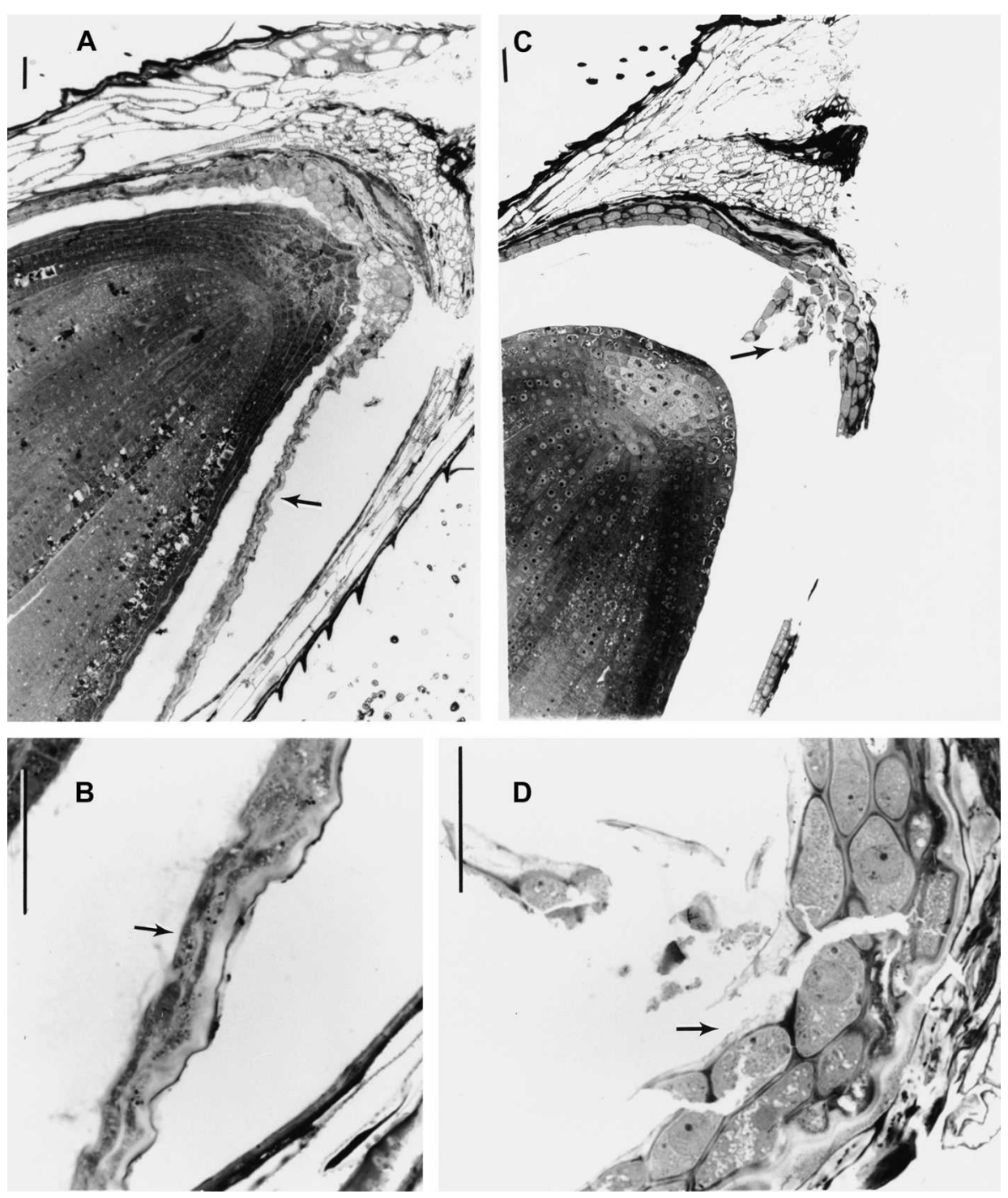

Fig. 6. Thin sections of 'Everglades' lettuce seeds matured at $20 / 10{ }^{\circ} \mathrm{C}$ (day/night on a 12 -h photoperiod) and subsequently imbibed at $36{ }^{\circ} \mathrm{C}$ for $11 \mathrm{~h}$. A total of $50 \%$ of the seeds germinated. (A) Disruption at the side of the endosperm. (B) Dense cytoplasm around the area in A. (C) Endosperm separated from the integument. (D) Closeup of cracks in the endosperm from the area of disruption in $\mathrm{C}(\mathrm{bar}=30 \mu \mathrm{m})$. imbibition (Fig. 8D-E). The endosperm layer had separated from the integument. As the radicle elongated, the endosperm cell walls appeared to dissolve and then rupture.

Endosperm CELL number. The micropylar area of the endosperm layer was more than two cells thick. Endosperm cells in the micropylar area of 'Dark Green Boston' and 'Everglades' seeds matured at 20/10 and $30 / 20{ }^{\circ} \mathrm{C}$ were counted (Table 3 ). To do this, cells in each vertical layer, here termed a column, a vertical direction from the inner side close to the embryo to the outer side close to the integument, were counted (Fig. 9). Counting began from the number of endosperm cells in excess of two and ended where the number of endosperm cells returned to two (Table 3 ). Seed maturation temperature regime had a greater effect on cell number than the genotypes.

Seeds of 'Dark Green Boston' matured at $20 / 10{ }^{\circ} \mathrm{C}$ had more endosperm cells in the micropylar area compared with the seeds matured at $30 / 20{ }^{\circ} \mathrm{C}$. Cells increased not only in the number of cells in the column, but also in the number of columns with more than two cells. For seeds matured at $20 / 10^{\circ} \mathrm{C}$, the average number of endosperm columns with more than two cells was 14 columns compared with seven for seeds matured at $30 / 20{ }^{\circ} \mathrm{C}$. At the center of the micropylar end (C in Table 3), cell number per column was greatest. Seeds matured at $20 / 10^{\circ} \mathrm{C}$ had 4.7 cells per column, and there were four columns with more than 3.3 cells. For seeds matured at $30 / 20{ }^{\circ} \mathrm{C}$, only the central column had 3.3 cells.

The endosperm cells of seeds matured at $30 / 20^{\circ} \mathrm{C}$ had large, round vacuoles and dense cytoplasm (Fig. 7A-B) once imbibed at $36{ }^{\circ} \mathrm{C}$ for $11 \mathrm{~h}$. Part of the endosperm layer had separated from the integument and the cells in this region were flat with a dense cytoplasm. The thin endosperm layer had separated from the integument (Fig. 7C-D).

PI 251245. Germination at $36^{\circ} \mathrm{C}$ of seeds matured at $20 / 10^{\circ} \mathrm{C}$ was $33 \%\left(\mathrm{~T}_{50}=26 \mathrm{~h}\right)$ and for seeds matured at $30 / 20{ }^{\circ} \mathrm{C}$, germination was $97 \%\left(T_{50}=12 \mathrm{~h}\right)($ Table 2$)$. Seeds matured at $20 / 10{ }^{\circ} \mathrm{C}$ had endosperm tissue consisting of round cells and dense cytoplasm (Fig. 8A-B). Part of the endosperm layer in the micropylar region had separated from the integument, and all cells contained dense cytoplasm (Fig. 8B-C). The endosperm cell layer was observed as disrupted in the micropylar region of these seeds but was still attached to the integument tissue.

In seeds matured at $30 / 20{ }^{\circ} \mathrm{C}$, the endosperm layer at the radicle end was disrupted, and the cell walls on the lateral side of the endosperm tissue were nearly broken after $6 \mathrm{~h}$ of
'Everglades' seeds matured at $20 / 10$ and $30 / 20^{\circ} \mathrm{C}$ had nearly the same number of columns containing more than two endosperm cells in the micropylar area. Seeds matured at $20 / 10{ }^{\circ} \mathrm{C}$ had five columns with more than 3.5 cells, whereas seeds matured at $30 / 20{ }^{\circ} \mathrm{C}$ had no columns with more than 3.5 cells.

\section{Discussion}

Thermosensitivity was circumvented in lettuce seeds by producing seeds at $30 / 20{ }^{\circ} \mathrm{C}$ or by seed priming (Sung et al., 1998a, 1998b). When primed lettuce seeds were imbibed, seed germination was rapid and uniform, so the restrictions to germination were bypassed at supraoptimal temperature (Guedes and Cantliffe, 1980). Mechanisms related to how priming increases embryonic growth or weakens the endosperm in lettuce seeds have been studied by Bradford (1986), Cantliffe et al. (1984), Karssen et al. (1989), and Nascimento et al. (2001). In related work, Sung et al. (1998a) reported that 

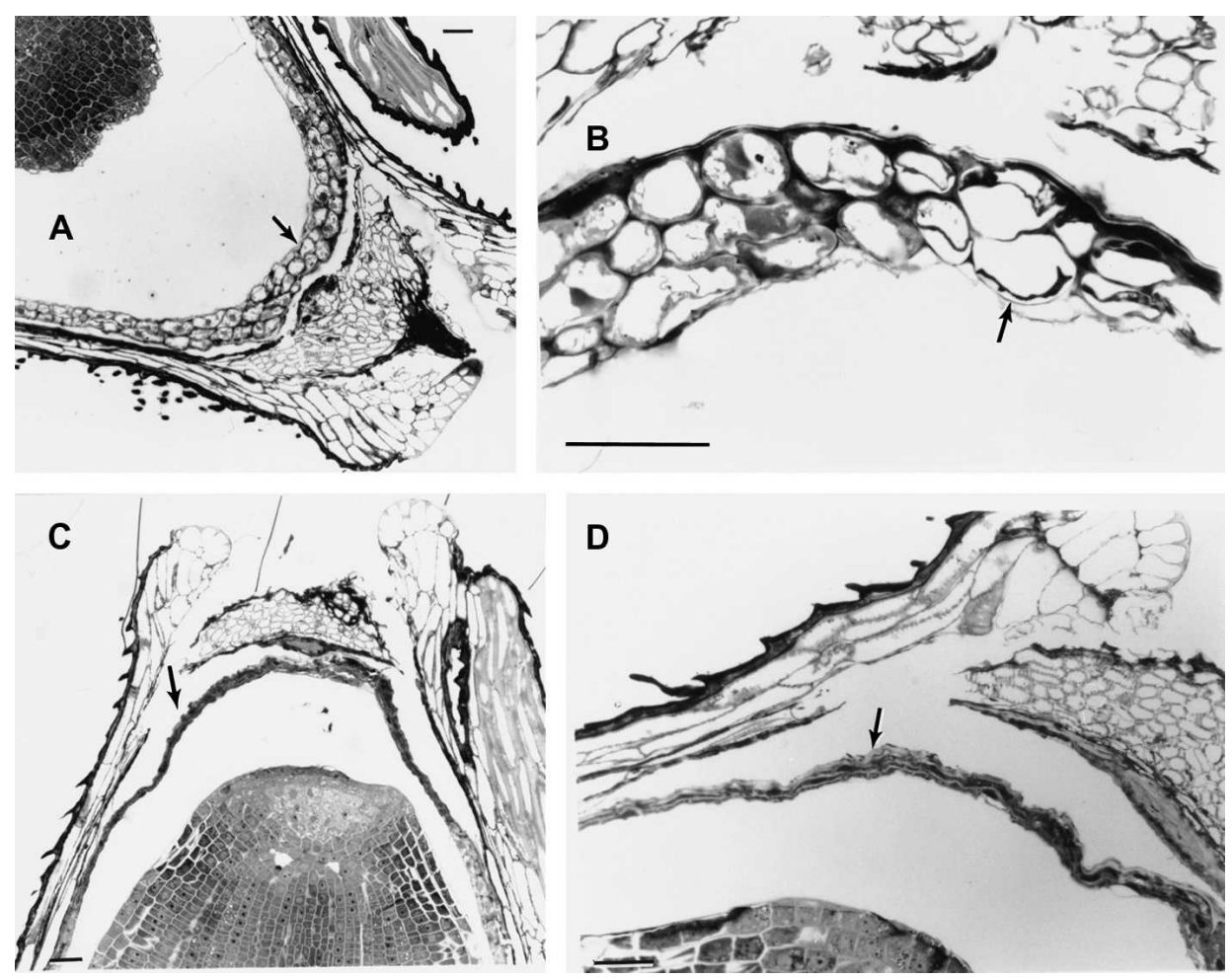

Fig. 7. Thin sections of 'Everglades' lettuce seeds matured at $30 / 20^{\circ} \mathrm{C}$ (day/night on a 12 -h photoperiod) and subsequently imbibed at $36^{\circ} \mathrm{C}$ for $11 \mathrm{~h}$. A total of $98 \%$ of the seeds germinated. (A) Empty endosperm cell and condensed cytoplasm. (B) Closeup of A (rotated). (C) Endosperm separated from the integument showing dense cytoplasm in this area. Irregular shape of the radicle apex denotes growth. (D) Closeup of C (rotated) $(\mathrm{bar}=30 \mu \mathrm{m})$.

priming led to a reduction in initial force necessary to penetrate the endosperm, integument, and pericarp. The radicle protruded through the weakened area(s) of the seeds. During priming, Guedes et al. (1981) viewed morphological changes in 'Minetto' lettuce seeds using scanning microscopy and reported that the plasma membrane of endosperm cells gradually loosened. This loosening may suggest endosperm cell weakening and may contribute to enhanced seed germination in primed seeds at high temperature. Increased endo- $\beta$-mannanase activity was observed during lettuce seed priming, and enzyme activity persisted in primed seeds after seed drying and rehydration (Nascimento et al., 2001). These authors suggested that priming may overcome the inhibitory effect of high temperature in seeds of thermosensitive cultivars such as 'Dark Green Boston' as a result of increased enzyme activity, especially in the micropylar endosperm region in front of the radicle tip.

Structural changes have been observed in the micropylar area of lettuce seeds before radicle protrusion (Georghiou et al., 1983; Psaras et al., 1981). Theses changes were not observed in seeds imbibed under adverse germination conditions, including high temperatures. Results of the present anatomical study indicated that structural alterations of the endosperm in front of the radicle tip was necessary for normal germination. The integument and pericarp did not appear to play major roles in restricting seed germination during incubation at high temperature because in all seeds, these tissues split on one side of the micropylar area during imbibition, regardless of seed maturation temperature or priming. The endosperm layer directly in front of the radicle appeared to be the area of critical resistance to seed germination at high temperature.
The typical lettuce endosperm cell has a thick cell wall consisting primarily of polysaccharides; the micropylar walls are rich in arabinose and glucose, and the lateral walls are rich in galactomannan (Dutta et al., 1994; Nascimento and Cantliffe, 2001). Using the same seed lots and genotypes as in the present research, Nascimento et al. (2000) verified that seeds from the thermotolerant genotypes 'Everglades' and PI 251245 had greater activity of endo- $\beta$-mannanase, a cell-wall-bound enzyme, than the thermosensitive genotype 'Dark Green Boston'. Protein bodies are present in the vacuoles of the endosperm cells and, in germinating seeds, the dissolution of the food reserves occurs first in the micropylar area (Bewley and Halmer, 1980/1981; Dutta et al., 1997). When this dissolution occurs, part of the endosperm layer in the micropylar region is weakened and may rupture. Georghiou et al. (1983) and Psaras et al. (1981) also indicated that in germinating lettuce seeds, the endosperm cells next to the radicle were highly vacuolated before radicle protrusion and that storage materials appeared mobilized, although the endosperm cells in the lateral and cotyledonary area remained intact. Changes in the endosperm cell walls before radicle protrusion have been observed in other species and coincidentally with an increase in endo- $\beta$-manannase (Bewley, 1997; Bradford et al., 2000; Toorop et al., 2000).

Puncture tests (Sung et al., 1998a) and the anatomical studies presented here give further evidence that weakening of endosperm tissue around the radicle tip before radical emergence is related to regulation of germination at high temperature. Puncture tests also indicated that, in thermosensitive lettuce genotypes, the force required to penetrate the endosperm increased at higher imbibition temperatures (i.e., $36^{\circ} \mathrm{C}$ ). The level of puncture force resistance of the endosperm depended on genotype, and the timing of radicle emergence was controlled primarily by the rate at which the seed coverings weakened. A rupture in the loosened endosperm was noted sooner in primed seeds of 'Everglades' and PI 251245 than in nonprimed counterparts (Sung et al., 1998a). In both, the radicle elongated through this opening in the seed coverings. In primed seeds of 'Dark Green Boston' and nonprimed seeds of 'Everglades', the thin endosperm layer did not rupture but closely surrounded the embryo. The endosperm may resist complete rupturing until the radicle forcefully penetrated through a weakened endosperm, suggesting that the radicle may play a role in seed germination at supraoptimal temperature. Greater endo- $\beta$-manannase activity was observed in primed and nonprimed seeds of 'Everglades' lettuce as well as primed 'Dark Green Boston' seeds compared with nonprimed 'Dark Green Boston' seeds (Nascimento et al., 2001), suggesting that 

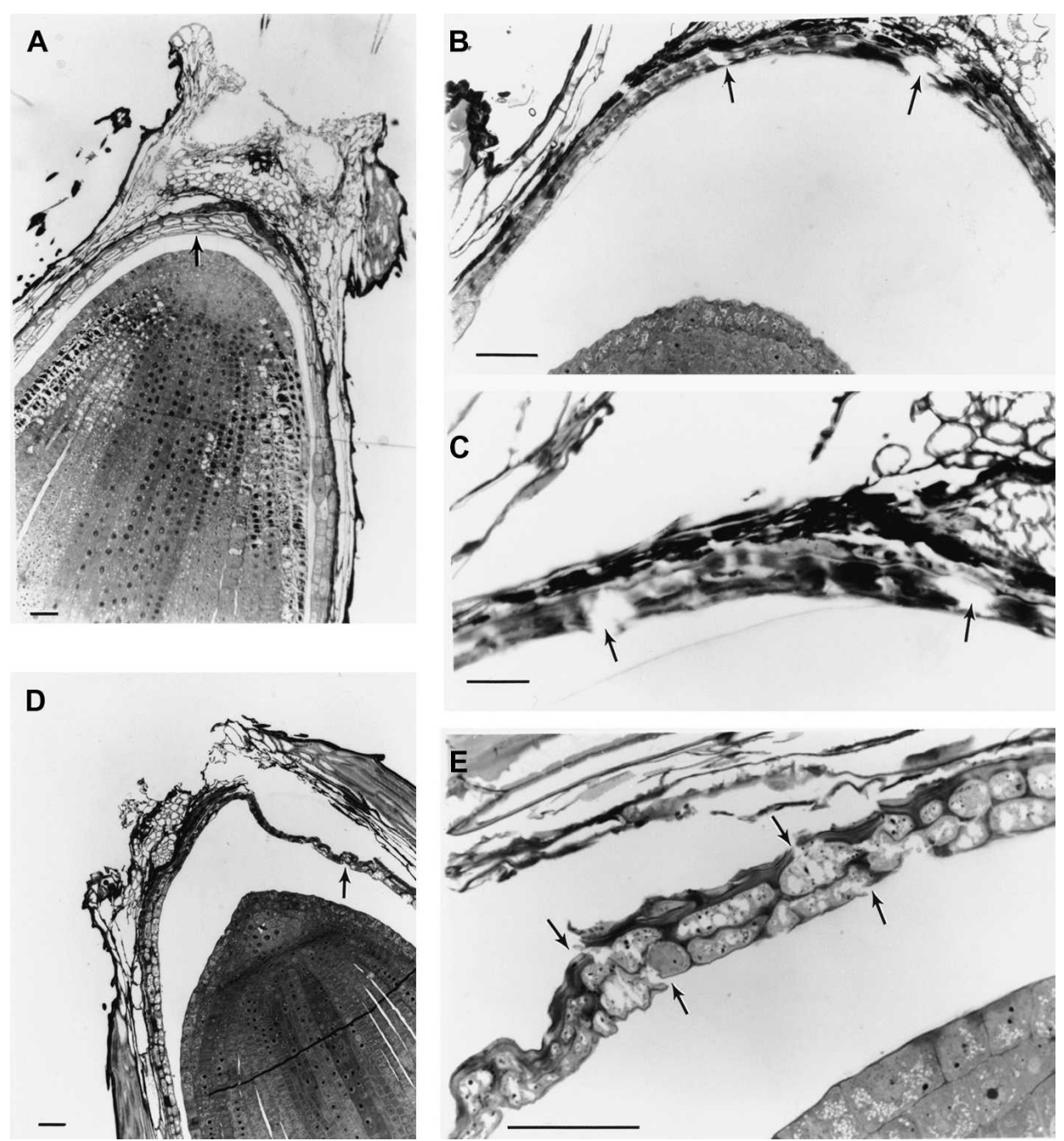

Fig. 8. Thin sections of PI 251245 lettuce seeds matured at $20 / 10{ }^{\circ} \mathrm{C}(\mathrm{A}-\mathrm{C})$ or $30 / 20^{\circ} \mathrm{C}(\mathrm{D}-\mathrm{E})$ (day/night on a 12 -h photoperiod) and subsequently imbibed at $36^{\circ} \mathrm{C}$ for $20 \mathrm{~h}(\mathrm{~A}-\mathrm{C})$ or $6 \mathrm{~h}(\mathrm{D}-\mathrm{E})$. The $20 / 10^{\circ} \mathrm{C}$ seed lots had $33 \%$ germination, whereas the $30 / 20{ }^{\circ} \mathrm{C}$ seed lot germinated at $97 \%$ at $36^{\circ} \mathrm{C}$. (A) Dense cytoplasm in micropylar area endosperm cells depicting a rupture. (B) Disruption of the endosperm cells of seeds imbibed for $20 \mathrm{~h}$ (before any radicle protrusion). (C) Closeup of B. (D) Shrunken endosperm separated from the integument of seeds imbibed for $6 \mathrm{~h}$. (E) Disintegration of the endosperm cell wall before radicle protrusion in seeds imbibed $6 \mathrm{~h}(\mathrm{bar}=30 \mu \mathrm{m})$. enzyme activity may also be related to seed germination at supraoptimal temperature.

For lettuce seed germination to occur, two mechanisms may operate. The endosperm may gradually weaken until it finally ruptures or the endosperm may weaken, but not sufficiently to rupture spontaneously so that the growing radicle must provide sufficient force to penetrate the endosperm.

Cantliffe et al. (1984) suggested that the turgor pressure of the lettuce radicle must be increased if cell elongation was to occur. During lettuce seed germination, Srivastava and Paulson (1968) reported that the contents of protein bodies in the radicle and cotyledons were depleted and the protein bodies gradually became empty vacuoles. In the present work, it was observed that the protein bodies in the endosperm cells dissolved during imbibition. Bewley and Halmer (1980/1981) noted that this degradation of stored reserves in the endosperm diffused to the cotyledons and were hydrolyzed to small molecules, which, presumably, were then absorbed by the cotyledons for use by the growing seedling. In primed seeds, this degradation of endosperm cell reserves may decrease osmotic potential thereby enhancing the ability of the radicle to absorb water and grow and so promote germination.

Seeds of all genotypes used in this work matured at $30 / 20{ }^{\circ} \mathrm{C}$ overcame thermoinhibition and germinated rapidly at $36^{\circ} \mathrm{C}$. The timing of the series

Table 3. Average endosperm cell numbers in the micropylar area of lettuce seeds matured at two temperature regimes.

\begin{tabular}{|c|c|c|c|c|c|c|c|c|c|c|c|c|c|c|c|}
\hline \multirow[b]{3}{*}{ Genotype } & \multirow{3}{*}{$\begin{array}{l}\text { Maturation } \\
\text { temp }\end{array}$} & \multicolumn{14}{|c|}{ Column location $^{z}$} \\
\hline & & L6 & L5 & L4 & L3 & $\mathrm{L} 2$ & $\mathrm{~L} 1$ & $\mathrm{C}$ & R1 & $\mathrm{R} 2$ & R3 & $\mathrm{R} 4$ & R5 & R6 & $\mathrm{R} 7$ \\
\hline & & \multicolumn{14}{|c|}{ Avg endosperm cells (no.) } \\
\hline Dark Green & $20 / 10^{\circ} \mathrm{C}$ & 2.3 & 2.4 & 2.6 & 2.9 & 3.5 & 4.0 & 4.7 & 3.4 & 3.3 & 3.0 & 2.7 & 2.4 & 2.3 & 2.2 \\
\hline \multirow{2}{*}{ Boston } & $30 / 20{ }^{\circ} \mathrm{C}$ & & & & 2.3 & 3.0 & 2.8 & 3.3 & 2.8 & 2.8 & 2.3 & & & & \\
\hline & $\pm \mathrm{SE}^{\mathrm{w}}$ & & & & 0.3 & 0.6 & 0.4 & 0.9 & 0.6 & 0.6 & 0.3 & & & & \\
\hline \multirow[t]{3}{*}{ Everglades } & $20 / 10^{\circ} \mathrm{C}$ & & 2.1 & 2.2 & 3.2 & 3.8 & 4.3 & 4.6 & 4.0 & 3.7 & 3.4 & 3.0 & 2.6 & 2.2 & \\
\hline & $30 / 20{ }^{\circ} \mathrm{C}$ & & 2.0 & 2.9 & 3.1 & 3.2 & 3.1 & 3.4 & 3.1 & 3.1 & 3.0 & 2.8 & 2.4 & & \\
\hline & $\pm \mathrm{SE}^{\mathrm{W}}$ & & 0.1 & 0.2 & 0.1 & 0.4 & 0.4 & 0.7 & 0.4 & 0.4 & 0.0 & 0.2 & 0.3 & & \\
\hline
\end{tabular}

${ }^{\mathrm{z}} \mathrm{C}=$ central column, $\mathrm{L}=$ left of $\mathrm{C}, \mathrm{R}=$ right of $\mathrm{C}$ (see Fig. 9).

${ }^{\mathrm{y}}$ Day/night temperature on a 12-h photoperiod.

${ }^{x}$ Values of mean \pm SE of four replications.

${ }^{\mathrm{w}}$ Values of mean $\pm \mathrm{SE}$ of three replications. 


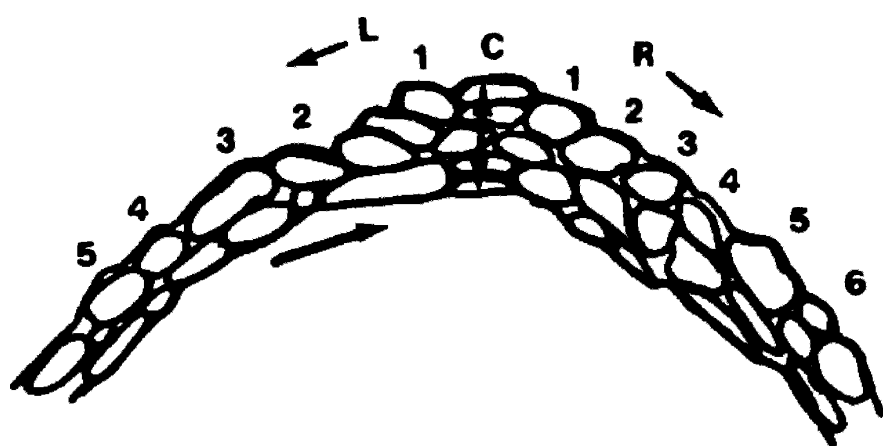

Fig. 9. Diagram of micropylar region of lettuce seed endosperm cell column locations.

of events between vacuolation of the endosperm cell and endosperm cell wall disruption is not clear. In 'Dark Green Boston' and PI 251245 seeds matured at $30 / 20^{\circ} \mathrm{C}$, endosperm cell wall rupture was observed before the cytoplasm had condensed. Although it is not clear what the first step is for enhancing the cell wall rupture, Gray et al. (1988) suggested that cell wall weakening enzymes should have been synthesized during seed development and maturation. In fact, Nascimento et al. (2000) observed that 'Dark Green Boston' lettuce seeds produced at $30 / 20{ }^{\circ} \mathrm{C}$ compared with $20 / 10{ }^{\circ} \mathrm{C}$ had higher manannase activity before and during germination. These authors hypothesized that seed maturation at high temperature partially overcomes the inhibitory effect of high temperature on 'Dark Green Boston' seed germination by increasing manannase activity during the first hours of imbibition.

The endosperm layer of DGB and EVE matured at $20 / 10^{\circ} \mathrm{C}$ had more cells per endosperm column in the micropylar area than seeds matured at $30 / 20{ }^{\circ} \mathrm{C}$ (Table 3). In maize (Zea mays L.), high temperatures during seed development reduced the number of endosperm cells (Commuri and Jones, 1999) and cell number in carrot (Daucus carota L.) seed embryo was affected possibly because of difference in temperature during the period of seed growth (Gray et al., 1988). In the present work, seeds matured at $20 / 10{ }^{\circ} \mathrm{C}$ germinated poorly at $36{ }^{\circ} \mathrm{C}$. This poor germination may be related to increased mechanical resistance to germination resulting from a thicker endosperm (more cells per endosperm column) in the micropylar area. The mechanism(s) that contribute to endosperm thinning in seeds matured at high temperature remain unknown. Activation of synthesis of cell wall weakening enzymes during lettuce seed maturation (Gray et al., 1988) or residual activity (retention) of mannanase produced during seed development, as observed in tomato seeds (Hilhorst and Downie, 1996), may be related to the amount of endosperm cells in the micropylar area.

The several studies cited in this article provided evidence for the endosperm weakening to have lettuce seeds germinate at high temperature. Enhanced thermotolerance of thermosensitive lettuce cultivars achieved by seed development at high temperatures or seed priming led to similar endosperm structural alterations during germination. Those structural modifications in the lettuce endosperm opposite the radicle tip were observed before radicle protrusion. The present study suggests that the mechanisms of a thermotolerant genotype, maturation temperature, and seed priming may be linked and that each variable helped to circumvent thermodormancy by releasing the physical resistance of the endosperm, possibly through involvement of a cell wall enzyme.

\section{Literature Cited}

Bewley, J.D. 1997. Breaking down the wall-A role for endo- $\beta$ mannanase in release from seed dormancy? Trends Plant Sci. 2: 464-469.

Bewley, J.D. and P. Halmer. 1980. 1981. Embryo-endosperm interactions in the hydrolysis of lettuce seed reserves. Israel J. Bot. 29:118-132.

Bonina, J.R., D.J. Cantliffe, P.J. Stofella, and D.J. Huber. 2007. A rapid and inexpensive test for determining optimal hydrothermal timing for priming lettuce seed. Seed Technol. 29:37-49.

Borthwick, H.A. and W.W. Robbins. 1928. Lettuce seed and its germination. Hilgardia 3:275-304.

Bradford, K.J. 1986. Manipulation of seed water relations via osmotic priming to improve germination under stress conditions. HortScience 21:1105-1112.

Bradford, K.J., J. Argyris, P. Dahal, L. O'Brien, M.J. Truco, O. Ochoa, D.W. Still, R. Grube, R. Hayes, and R.W. Michelmore. 2006. Genetic analysis of lettuce seed thermodormancy, p. 13. International Society for Horticultural Science: 4th International Symposium on Seed, Transplant and Stand Establishment of Horticultural Crops, 3-6 Dec. 2006, San Antonio, TX(abstr.).

Bradford, K.J., F. Chen, M.B. Cooley, P. Dahal, B. Downie, K.K. Fukunaga, O.H. Gee, S. Gurushingue, R.A. Mella, H. Nonogaki, C.T. $\mathrm{Wu}, \mathrm{H}$. Yang, and K.O. Yim. 2000. Gene expression prior to radicle emergence in imbibed tomato seeds, p. 231-251. In: Black, M., K.J. Bradford, and J. Vazquez-Ramos (eds.). Seed biology: Advances and applications. CABI, Wallingford, UK.

Bradford, K.J. and O.A. Somasco. 1994. Water relations of lettuce seed thermoinhibition. I: Priming and endosperm effects on base water potential. Seed Sci. Res. 4:1-10.

Cantliffe, D.J., J.M. Fischer, and T.A. Nell. 1984. Mechanism of seed priming in circumventing thermodormancy in lettuce. Plant Physiol. 75:290-294.

Cantliffe, D.J., K.D. Shuler, and A.C. Guedes. 1981. Overcoming seed thermodormancy in a heat sensitive romaine lettuce by seed priming. HortScience 16:196-198.

Cantliffe, D.J., Y. Sung, and W.M. Nascimento. 2000. Lettuce seed germination. Hort. Rev. (Amer. Soc. Hort. Sci.) 24:229-275.

Commuri, P.D. and R.J. Jones. 1999. Ultrastructural characterization of maize (Zea mays L.) kernels exposed to high temperature during endosperm cell division. Plant Cell Environ. 22:375-385.

Dahal, P., D.J. Nevins, and K.J. Bradford. 1997. Relationships of endo$\beta$-mannanase activity and cell wall hydrolysis in tomato endosperm to germination rates. Plant Physiol. 113:1243-1252.

Dutta, S. and K.J. Bradford. 1994. Water relations of lettuce seed thermoinhibition. II: Ethylene and endosperm effects on base water potential. Seed Sci. Res. 4:11-18.

Dutta, S., K.J. Bradford, and D.J. Nevins. 1994. Cell-wall autohydrolysis in isolated endosperms of lettuce. Plant Physiol. 104:623628

Dutta, S., K.J. Bradford, and D.J. Nevins. 1997. Endo- $\beta$-mannanase activity present in cell wall extracts of lettuce endosperm prior to radicle emergence. Plant Physiol. 113:155-161.

Georghiou, K., G. Psaras, and K. Mitrakos. 1983. Lettuce endosperm structural changes during germination under different light, temperature, and hydration conditions. Bot. Gaz. 144:207-211.

Gonai, T., S. Kawahara, M. Tougou, S. Satoh, T. Hashiba, N. Hirai, H. Kawaide, Y. Kamyia, and T. Yoshyoka. 2004. Abscisic acid in the thermoinhibition of lettuce seed germination and enhancement of its catabolism by gibberellins. J. Expt. Bot. 55:111-118.

Gong, X., G.W. Bassel, A. Wang, J.S. Greenwood, and J.D. Bewley. 2005. The emergence of embryos from hard seeds is related to the structure of the cell walls of the micropylar endosperm, and not to endo- $\beta$-mannanase activity. Ann. Bot. (Lond.) 96:1165-1173. 
Gray, D., D.C.E. Wurr, J.A. Ward, and J.R. Fellows. 1988. Influence of post-flowering temperature on seed development, and subsequent performance of crisp lettuce. Ann. Appl. Biol. 113:391 402.

Groot, S.P.C. and C.M. Karssen. 1987. Gibberellins regulate seed germination in tomato by endosperm weakening: A study with gibberellin-deficient mutants. Planta 171:525-531.

Guedes, A.C. and D.J. Cantliffe. 1980. Germination of lettuce seeds at high temperature after seed priming. J. Amer. Soc. Hort. Sci. 105:777-781.

Guedes, A.C., D.J. Cantliffe, and T.A. Nell. 1981. Morphological changes during lettuce seed priming and subsequent radicle development. J. Amer. Soc. Hort. Sci. 106:121-126.

Hall, J.C. and C. Hawes. 1991. Electron microscopy of plant cells. Academic Press, New York.

Halmer, P., J.D. Bewley, and T.A. Thorpe. 1975. Enzyme to breakdown lettuce endosperm cell wall during gibberellin-and-lightinduced germination. Nature 258:716-718.

Halmer, P., J.D. Bewley, and T.A. Thorpe. 1976. An enzyme to degrade lettuce endosperm cell walls: Appearance of a mannanase following phytochrome- and gibberellin-induced germination. Planta 130:189-196.

Hilhorst, H.W. and W.M. Downie. 1996. Primary dormancy in tomato (Lycopersicon esculentum cv. Moneymaker)-Studies with the sitiens mutant. J. Expt. Bot. 47:89-97.

Ikuma, H. and K.V. Thimann. 1963. The role of the seed-coats in germination of photosensitive lettuce seeds. Plant Cell Physiol. $4: 169-185$.

Jones, R.L. 1974. The structure of the lettuce endosperm. Planta 121:133-146.

Karssen, C.M., A. Haigh, P. vander Toorn, and R. Weges. 1989. Physiological mechanisms involved in seed priming, p. 269-280 In: Taylorson, R.B. (ed.). Recent advances in the development and germination of seeds. Plenum Press, New York.

Khan, A.A. 1992. Preplant physiological seed conditioning. Hort. Rev. (Amer. Soc. Hort. Sci.) 13:131-181.

Khan, A.A., H.H. Peck, and C. Samimy. 1980. 1981. Seed osmoconditioning: Physiological and biochemical changes. Israel J. Bot. 29:133-144.

Khan, A.A., K.-L. Tao, J.S. Knypl, and B. Bonkowska. 1978. Osmotic conditioning of seeds: Physiological and biochemical changes. Acta Hort. 83:267-278.

Koller, D. 1962. Preconditioning of germination in lettuce at time of fruit ripening. Amer. J. Bot. 49:841-843.

Kozarewa, I., D.J. Cantliffe, R.T. Nagata, and H.J. Klee. 2004. New support for the involvement of ethylene in lettuce germination at supra-optimal temperature. Acta Hort. 631:31-37.

Kozarewa, I., D.J. Cantliffe, R.T. Nagata, and P.J. Stoffella. 2006. High maturation temperature of lettuce seeds results in increased ethylene production and germination at elevated temperatures. J. Amer. Soc. Hort. Sci. 131:564-570.

Leviatov, S., O. Shoseyov, and S. Wolf. 1995. Involvement of endomannanase in the control of tomato seed germination under low temperature conditions. Ann. Bot. (Lond.) 76:1-6.

Marraccini, P., W.J. Rogers, C. Allard, M.L. Andre, V. Caillet, N. Lacoste, F. Lausanne, and S. Michaux. 2001. Molecular and biochemical characterization of endo- $\beta$-mannanases from germinating coffee (Coffea arabica) grains. Planta 213:296-308.

McDowell, E.M., F. Benjamin, and M.D. Trump. 1976. Histological fixatives suitable for diagnostic light and electron microscopy. Arch. Pathol. Lab. Med. 100:405-414.

Mo, B. and J.D. Bewley. 2003. The relationship between $\beta$-mannosidase and endo- $\beta$-mannanase activities in tomato seeds during and following germination: A comparison of seed population and individual seeds. J. Expt. Bot. 51:1381-1387.

Müller, K., S. Tintelnot, and G. Leubner-Metzger. 2006. Endospermlimited Brassicaceae seed germination: Abscisic acid inhibits embryo-induced endosperm weakening of Lepidium sativum (cress) and endosperm rupture of cress and Arabidopsis thaliana. Plant Cell Physiol. 47:864-877.

Nabors, M.W. and A. Lang. 1971a. The growth physics and water relations of red-light induced germination in lettuce seeds. I. Embryos germinating in osmoticum. Planta 101:1-25.

Nabors, M.W. and A. Lang. 1971b. The growth physics and water relations of red-light induced germination in lettuce seeds. II. Embryos germinating in water. Planta 101:26-42.

Nascimento, W.M. and D.J. Cantliffe. 1998. Performance of lettuce primed seeds during storage. Proc. Florida State Hort. Soc. 111: 96-99.

Nascimento, W.M. and D.J. Cantliffe. 2001. Composicao quimica do endosperma, atividade enzimatica e sua associacao com a germinacao das sementes de alface em altas temperaturas. Revista Brasileira de Sementes 23:121-126.

Nascimento, W.M., D.J. Cantliffe, and D.J. Huber. 2000. Thermotolerance in lettuce seeds: Association with ethylene and endo- $\beta$ mannanase. J. Amer. Soc. Hort. Sci. 125:518-524.

Nascimento, W.M., D.J. Cantliffe, and D.J. Huber. 2001. Endo- $\beta$ mannanase activity and seed germination of thermosensitive and thermotolerant lettuce genotypes in response to seed priming. Seed Sci. Res. 11:255-264.

Nascimento, W.M., D.J. Cantliffe, and D.J. Huber. 2004. Ethylene evolution and endo- $\beta$-mannanase activity during lettuce seed germination at high temperature. Sci. Agr. 61:156-163.

Nascimento, W.M., D.J. Cantliffe, and D.J. Huber. 2005. Seed aging affects ethylene production and endo- $\beta$-mannanase activity during lettuce seed germination at high temperature. Seed Sci. Technol. 33:11-17.

Nijsse, J., E. Erbe, N.B.M. Brantjes, J.H.N. Schel, and W.P. Wergin. 1998. Low-temperature scanning electron microscopic observations on endosperm in imbibed and germinated lettuce seeds. Can. J. Bot. 76:509-516.

Nonogaki, H., F. Chen, and K.J. Bradford. 2007. Mechanisms and genes involved in germination sensu stricto, p. 264-304. In: Bradford, K.J. and H. Nonogaki (eds.). Seed development, dormancy and germination. Blackwell Publishing, Oxford, UK.

Nonogaki, H., O.H. Gee, and K.J. Bradford. 2000. A germinationspecific endo- $\beta$-mannanase gene is expressed in the micropylar endosperm cap of tomato seeds. Plant Physiol. 123:1235-1245.

Nonogaki, N. and Y. Morohashi. 1999. Temporal and spatial pattern of the development of endo- $\beta$-mannanase activity in germinating and germinated lettuce seeds. J. Expt. Bot. 50:1307-1313.

Nonogaki, N., M. Nomaguchi, and Y. Morohashi. 1995. Endo- $\beta-$ mannanases in the endosperm of germinated tomato seeds. Physiol. Plant. 94:328-334.

Ouellette, B.F.F. and J.D. Bewley. 1986. $\beta$-Mannoside mannohydrolase and the mobilization of the endosperm cell wall of lettuce seed, cv. Grand Rapids. Planta 169:333-338.

Pavlista, A.D. and A.H. Haber. 1970. Embryo expansion without protrusion in lettuce seeds. Plant Physiol. 46:636-637.

Pavlista, A.D. and J.G. Valdovinos. 1975. Carboxymethlycellulase activity prior to the onset of germination of lettuce seeds. Plant Physiol. 56:83 (abstr.).

Pavlista, A.D. and J.G. Valdovinos. 1978. Changes in the surface appearance of the endosperm during lettuce achene germination. Bot. Gaz. 139:171-179.

Psaras, G., K. Georghiou, and K. Mitrakos. 1981. Red-light-induced endosperm preparation for radicle protrusion of lettuce embryos. Bot. Gaz. 142:13-18.

Sanchez, R.A. and L. Miguel. 1997. Phytochrome promotion of mannan-degrading enzyme activities in the micropylar endosperm of Datura ferox seeds requiring the presence of embryo and gibberellin synthesis. Seed Sci. Res. 7:27-33.

Silva, E.A.A., P.E. Toorop, J. Nijsse, J.D. Bewley, and H.W.M. Hilhorst. 2005. Exogenous gibberellins inhibit coffee (Coffea arabica cv. Rubi) seed germination and cause cell death in the embryo. J. Expt. Bot. 56:1029-1038. 
Speer, H.L. 1974. Some aspects of the function of the endosperm during the germination of lettuce seeds. Can. J. Bot. 52:1117-1121. Srivastava, L.M. and R.E. Paulson. 1968. The fine structure of the embryo of Lactuca sativa. II. Changes during germination. Can. J. Bot. 46:1447-1461.

Still, D.W. and K.J. Bradford. 1997. Endo- $\beta$-mannanase activity from individual tomato endosperm caps and radicle tips in relation to germination rate. Plant Physiol. 113:21-29.

Sung, Y. 1996. Identification and characterization of thermo-tolerance in lettuce seed germination, University of Florida, PhD Diss.

Sung, Y., D.J. Cantliffe, and R.T. Nagata. 1998a. Using a puncture force test to identify the role of seed coverings on germination of thermotolerant lettuce seed. J. Amer. Soc. Hort. Sci. 123:1102-1106.

Sung, Y., D.J. Cantliffe, and R.T. Nagata. 1998b. Seed developmental temperature regulation of thermotolerance in lettuce. J. Amer. Soc. Hort. Sci. 123:700-705.

Tao, K.L. and A.A. Khan. 1979. Changes in the strength of lettuce endosperm during germination. Plant Physiol. 63:126-128.

Toorop, P.E., A.C. Aelst, and H.W.M. Hilhorst. 2000. The second step of the biphasic endosperm cap weakening that mediates tomato
(Lycopersicon esculentum) seed germination is under control of ABA. J. Expt. Bot. 51:1371-1379.

Toorop, P.E., J.D. Bewley, and H.W.M. Hilhorst. 1996. Endo- $\beta$ mannanase isoforms are present in the endosperm of tomato seeds, but are not essentially linked to the completion of germination. Planta 200:153-158.

Wang, A.X., J.R. Li, and J.D. Bewley. 2004. Molecular cloning and characterization of an endo- $\beta$-mannanase gene expressed in the lettuce endosperm following radicle emergence. Seed Sci. Res. 14:267-276.

Watkins, J.T. and D.J. Cantliffe. 1983. Mechanical resistance of the seed coat and endosperm during germination of Capsicum annuum at low temperature. Plant Physiol. 72:146-150.

Welbaum, G.E., W.J. Muthui, J.H. Wilson, R.L. Grayson, and R.D. Fell. 1995. Weakening of muskmelon perisperm envelope tissue during germination. J. Expt. Bot. 45:391-400.

Willians, H.A., J.D. Bewley, J.S. Greenwood, R. Bourgault, and B. Mo. 2001. The cell walls of the endosperm of Asparagus officinalis seeds during development and following germination. Seed Sci. Res. $11: 305-315$. 